\title{
The Impact of Cultural Intelligence on Social Skills among University Students
}

\author{
Kenan KOÇ ${ }^{1} \&$ Mehmet Behzat TURAN ${ }^{1}$ \\ ${ }^{1}$ Erciyes University, School of Physical Education and Sports, Kayseri, Turkey \\ Correspondence: Kenan Koç, Erciyes University, School of Physical Education and Sports, 38039, Kayseri, \\ Turkey.
}

Received: April 30, 2018

Accepted: June 8, $2018 \quad$ Online Published: November 17, 2018

doi:10.5539/jel.v7n6p241

URL: https://doi.org/10.5539/jel.v7n6p241

\begin{abstract}
This study aims to examine the impact of cultural intelligence on social skills among the students of the School of Physical Education and Sports. The research population consists of randomly selected 377 students. As data collection tools, the study uses Cultural Intelligence Scale, Social Skills Inventory and "Personal Information Form". The data obtained through the Personal Information Form, Cultural Intelligence Scale and Social Skills Inventory was statistically analyzed using SPSS 20.0 package program. The information about and inventory total scores of the candidates and factor points were presented by finding frequency (f) and percentage (\%) values. Pearson Moment Correlation Coefficient analysis (r) was performed to indicate the relationship between the points obtained from the scales while multiple regression analysis was performed to identify whether the points are predictor of each other. $(\beta)$

In the study, we found positive significant relationships between cultural intelligence dimensions -cognitive, metacognitive, motivational and behavioural skills- and social skills dimensions -emotional expressivity, emotional sensitivity, emotional control, social expressivity, social sensitivity and social control. An examination of the prediction of social skills by cultural intelligence reveals that cognitive, metacognitive, motivational and behavioural dimensions are predictor of social skills, and students' social skills improve with the increase in their cultural intelligence level.

Consequently, the significance of cultural intelligence and social skills is increasingly growing for maintaining successful, healthy and peaceful relationships between people. Individuals with higher cultural intelligence and sociability are expected to be more active in the education system while having a high level of willingness in learning activities. Particularly in the universities where various cultures coexist, students who can establish social relationships with their friends and professors will be more successful and enthusiastic about accepting positions to participate in international activities. The development of cultural intelligence and social skills will naturally improve students in social and cultural aspects, thus contributing to form the basis of a healthier world. For these reasons, it will be useful to provide training that enhance social skills in educational and training settings and carry out activities that increase interaction with other cultures such as student exchange programs and overseas educational tours in order to enhance cultural intelligence level.
\end{abstract}

Keywords: cultural intelligence, social skills, physical education

\section{Introduction}

Various organizational and individual strategies are used in managing intercultural differences. One of the most important of these is cultural intelligence (Mercan, 2016).

In relation to general intelligence defined as the ability to solve problems, to reach right conclusions by basing problems on right reasons, and to comprehend, cultural intelligence can be defined as the capability to understand, interpret and effectively manage cultural differences (Vedadi, Kheiri, \& Abbasalizadeh, 2010).

In other words, cultural intelligence is defined as an individual's capability to adjust their behaviours according to the requirements of the cultures they interact with, to communicate effectively with the individuals from other cultures and to adapt to cultural differences (Earley \& Ang, 2003; Van, Ang, \& Nielsen, 2007).

Peterson (2004) defines cultural intelligence as the ability to display behaviours using skills such as language or interpersonal relationships and qualities such as tolerance for ambiguity, flexibility that are adjusted to 
culture-based values and attitudes of people with whom one interacts. Conceptualized as the set of abilities that helps an individual to function effectively and become successful in a cross-cultural or multicultural setting, cultural intelligence is considered as an important criterion for managing working groups from different cultures, knowing, understanding and working with people from other nations, institutions and professions (Earley \& Ang, 2003). Individuals with cultural intelligence training and experience begin to notice cultural shifts even before the members of that culture. These individuals can tune their behaviours automatically when they encounter a conscious situation. Individuals with high cultural intelligence have high cognitive perception of their environment (Thomas \& Inkson, 2004). In addition, another significant aspect of culture is education and the most important function of education is ensuring the continuity of the culture created by individuals or the society. Education is one of the primary means of cultural knowledge transfer. Thus, every member of the society learns certain behaviours, improves such behaviours and changes them if necessary, because culture has a changeable character and education of every new generation can cause changes in culture (Köse, 2016). At this point, the concepts of cultural intelligence and education are intertwined systems that function according to the principle of mutual benefit.

It is highly important for an individual in the society to have skills that will draw positive reactions while preventing negative ones from other people, and to convey their feelings and ideas to the people they get into contact with. Also people wish to understand the feelings and ideas of the people with whom they interact as part of interpersonal communication, which is possible with individuals' having certain skills. Such behaviours are usually called as social skills (Başaran, 1994; Bacanl1, 1990; Aydın, 1985).

Bates and Harvey define social skills as the ability to express both positive and negative interpersonal feelings without worrying about losing social reward (Çakıl, 1998). Sorias, on the other hand, defines social skills as the qualities that help people to explain their positive or negative feelings in an appropriate way, to defend their individual rights, to ask others for help when necessary, and to reject the requests they do not approve (Sorias, 1986).

Segrin states that social skill is the competency to establish appropriate and effective relationships with other people. Moreover, people with adequate social skills can express themselves efficiently, understand others and desire to be perceived positively by other people (Segrin, 2001).

Vygotsky maintains that social learning also guides cognitive development. A well-arranged social setting for children may facilitate their cognitive development. The social environment children live in can be a source of the concepts in their mind (Ergün \& Özsüer, 2006). The more people children have in their surrounding and the more interaction they have with them personally in the context of social environment, the more words and concepts they will learn. Furthermore, Keskin (2007) states that social skills improve with the increase in academic success among the students whose academic success and social skills were analyzed. Walker, Colvin ve Ramsey (1995), Social skills; defined as a set of skills that students need to maintain and initiate positive social relationships with students, peers, teachers, families, and other community members.

Taking the abovementioned as a whole, we see that the concepts of cultural intelligence and social skills can be effective in different dimensions and levels in different areas of life. The most prominent of these areas is education. When reviewing literature, we can find studies on cultural intelligence and social skills, which usually deal with each concept separately or address them in relation to other subjects (Ekici, 2017; Şenol, 2015; Kalafat, 2006; Mercan, 2016; Şahin \& Gürbüz, 2012). However, there is no study that examines the concepts of cultural intelligence and social skills and their reflection in education at the same time.

In this respect, we believe that this study can remedy the said deficiency in the field of physical education and sports, and bring a different perspective to the field when considered in terms of the dimensions of cultural intelligence and social skills of the students in different departments in the School of Physical Education and Sports. In this context, the overall aim of the study is an examination of the relationship between cultural intelligence and social skills among the students of the School of Physical Education and Sports.

\section{Material-Method}

\subsection{Study Group}

In the study, relational screening model was used. The model can be defined as "a screening model aiming to determine the existence and/or level of covariance between two or among more than two variables" (Karasar, 2015).

The study is a descriptive one as it attempts to assess the relationships between cultural intelligence and social skills and demographical characteristics of the university students. 


\subsection{Data Collection Tools}

The study uses the following data collection tools: Cultural Intelligence Scale, Social Skills Inventory and Socio-Demographic Information Form.

\subsection{Formation of Volunteer Groups:}

Randomly selected 377 students from the School of Physical Education and Sports in Erciyes University participated in the study.

Table 1. Socio-demographic characteristics of the participants

\begin{tabular}{|c|c|c|c|}
\hline & Variables & $\mathrm{N}$ & $\%$ \\
\hline \multirow{2}{*}{ Gender } & Male & 221 & 58.6 \\
\hline & Female & 156 & 41.4 \\
\hline \multirow{3}{*}{ Age } & $18-21$ & 173 & 45.9 \\
\hline & $22-25$ & 188 & 49.9 \\
\hline & $26-29$ & 16 & 4.2 \\
\hline \multirow{4}{*}{ Department } & $\begin{array}{l}\text { Physical Education and Sports } \\
\text { Teaching }\end{array}$ & 134 & 35.5 \\
\hline & Coaching Education & 125 & 33.2 \\
\hline & Sports Management & 63 & 16.7 \\
\hline & Recreation Management & 55 & 14.6 \\
\hline \multirow{4}{*}{ Grade } & 1 & 39 & 10.3 \\
\hline & 2 & 190 & 50.4 \\
\hline & 3 & 100 & 26.5 \\
\hline & 4 & 48 & 12.7 \\
\hline \multirow{7}{*}{ Area of Residence } & Aegean Region & 13 & 3.4 \\
\hline & Mediterranean Region & 45 & 11.9 \\
\hline & Central Anatolia Region & 234 & 62.1 \\
\hline & Marmara Region & 9 & 2.4 \\
\hline & Black Sea Region & 9 & 2.4 \\
\hline & Eastern Anatolia Region & 28 & 7.4 \\
\hline & South-eastern Anatolia Region & 39 & 10.3 \\
\hline \multirow{3}{*}{ GPA } & $1.25-1.99$ & 65 & 17.2 \\
\hline & $2.00-2.99$ & 215 & 57.0 \\
\hline & $3.00-4.00$ & 97 & 25.7 \\
\hline
\end{tabular}

\subsection{Socio-Demographic Information Form}

Socio-demographic information form includes 6 questions in order to get information about the age, gender, department, grade, area of residence and grade point average of the participants.

\subsection{Cultural Intelligence Scale}

To assess cultural intelligence, the study uses the 20 -item scale developed by Ang et al. (2007). In the scale, four items measure metacognitive dimension of cultural intelligence (example item "I am conscious of the cultural knowledge I apply to cross-cultural interactions"), six items assess cognitive dimension (example item "I know the legal and economic systems of other cultures"), five items measure motivational dimension (example item "I enjoy interaction with people from different cultures") while five items evaluate behavioural dimension (example item "I change my verbal behaviour (e.g., accent, tone) when a cross-cultural interaction requires it"). The participants answered these items according to 7-Likert type scale. The average of the responses of the participants reflects the skill level in the relevant cultural intelligence dimension. Higher points indicate that the relevant skill level is also high. In the study, we found that Cronbach Alpha reliability coefficient of the dimensions forming the Cultural Intelligence Scale is above .70 (metacognitive dimension $\alpha=.80$, cognitive dimension $\alpha=.84$, motivational dimension $\alpha=.85$ and behavioural dimension $\alpha=.86$ ).

\subsection{Social Skills Inventory}

This inventory was developed by Riggio (1986). It includes the dimensions of emotional expressivity (EE), emotional sensitivity (ES), emotional control (EC), social expressivity (SE), social sensitivity (SS) and social control (SC). The reliability analysis conducted by Yüksel (2004) found $\mathrm{r}=.92$. The reliability coefficients of the dimensions in the Social Skills Inventory are as follows: .81 - Emotional Expressivity; .87 - Emotional 
Sensitivity; .80 - Emotional Control; .89 - Social Expressivity; .88 - Social Sensitivity and .89 - Social Control. The result of the convergent validity study conducted by Yüksel (2004) finds .63 correlation between the scale and Self Adjustment Scale. The convergent validity coefficient for the whole inventory is significant $(0.01)$. These findings prove the validity of the Social Skills Inventory. The explanations for the dimensions of the inventory are as follows: emotional expressivity dimension measures an individual's nonverbal communication skills. Emotional sensitivity dimension measures the skills to receive and analyze other people's nonverbal messages while emotional control dimension measures an individual's ability to arrange and control nonverbal reactions. Social expressivity dimension assesses verbal expression skills, and social sensitivity dimension measures the ability to analyze verbal messages. Finally, social control dimension assesses social role playing skills (Yüksel, 2004).

\subsection{Data Analysis}

The data obtained through Personal Information Form, Cultural Intelligence Scale and Social Skills Inventory was coded and entered into SPSS 20.0 package program through which the analyses were performed. The candidates' personal information and inventory total points, and factor points were presented by finding frequency (f) and percentage (\%) values. To indicate the relationship between the points obtained from the scales, Pearson Moment Product Correlation analysis (r) was conducted while multiple regression analysis was performed to determine whether the points are predictive of each other. $(\beta)$

\section{Findings}

Table 2. Descriptive statistics of the students' responses to the questionnaire

\begin{tabular}{lllll}
\hline & $\mathrm{N}$ & Minimum & Maximum & X \pm SS \\
\hline Metacognitive $^{1}$ & 377 & 5.00 & 73.00 & $19.17 \pm 4.52$ \\
Cognitive $^{2}$ & 377 & 5.00 & 56.00 & $16.11 \pm 4.71$ \\
Motivational $^{3}$ & 377 & 5.00 & 47.00 & $19.07 \pm 4.30$ \\
Behavioral $^{4}$ & 377 & 5.00 & 25.00 & $18.28 \pm 3.65$ \\
Total Cultural Intelligence $^{5}$ & 377 & 28.00 & 131.00 & $72.64 \pm 12.30$ \\
\hline Emotional Expressivity $^{6}$ & 377 & 29.00 & 100.00 & $45.49 \pm 7.68$ \\
Emotional Sensitivity $^{7}$ & 377 & 30.00 & 116.00 & $52.71 \pm 10.29$ \\
Emotional Control $^{8}$ & 377 & 28.00 & 104.00 & $45.56 \pm 8.32$ \\
Social Expressivity $^{9}$ & 377 & 30.00 & 113.00 & $51.31 \pm 9.83$ \\
Social Sensitivity $^{10}$ & 377 & 25.00 & 90.00 & $48.51 \pm 8.32$ \\
Social Control $^{11}$ & 377 & 33.00 & 100.00 & $49.26 \pm 8.54$ \\
Social Skills $^{12}$ & 377 & 221.00 & 422.00 & $292.59 \pm 27.27$ \\
\hline
\end{tabular}

As is seen in Table 2, the university students' mean scores for the four dimensions of cultural intelligence are as follows: 19.17 for metacognitive dimension, 16.11 for cognitive dimension, 19.07 for motivational dimension, 18.28 for behavioural dimension. On the other hand, the mean scores for social skills dimensions are as follows: 45. 49 for emotional expressivity, 52.71 for emotional sensitivity, 45.56 for emotional control, 51.31 for social expressivity, 48.51 for social sensitivity and 49.26 for social control.

Table 3. Correlation coefficients between students' cultural intelligence and social skills $(\mathrm{N}=377)$

\begin{tabular}{|c|c|c|c|c|c|c|c|c|c|c|c|}
\hline & & 1 & 2 & 3 & 4 & 5 & 6 & 7 & 8 & 9 & 10 \\
\hline \multirow{3}{*}{ Metacognitive $^{1}$} & $\mathrm{r}$ & 1 & & & & & & & & & \\
\hline & $\mathrm{p}$ & & & & & & & & & & \\
\hline & $\mathrm{N}$ & 377 & & & & & & & & & \\
\hline \multirow{3}{*}{ Cognitive $^{2}$} & $\mathrm{r}$ & $.248^{* *}$ & 1 & & & & & & & & \\
\hline & $\mathrm{p}$ & .000 & & & & & & & & & \\
\hline & $\mathrm{N}$ & 377 & 377 & & & & & & & & \\
\hline \multirow{3}{*}{ Motivational $^{3}$} & $\mathrm{r}$ & $.368^{* *}$ & $.370^{* *}$ & 1 & & & & & & & \\
\hline & $\mathrm{p}$ & .000 & .000 & & & & & & & & \\
\hline & $\mathrm{N}$ & 377 & 377 & 377 & & & & & & & \\
\hline \multirow{3}{*}{ Behavioral $^{4}$} & $\mathrm{r}$ & $.307^{* *}$ & $.386^{* *}$ & $.432^{* *}$ & 1 & & & & & & \\
\hline & $\mathrm{p}$ & .000 & .000 & .000 & & & & & & & \\
\hline & $\mathrm{N}$ & 377 & 377 & 377 & 377 & & & & & & \\
\hline \multirow{3}{*}{$\begin{array}{l}\text { Emotional } \\
\text { Expressivity }^{5}\end{array}$} & $\mathrm{r}$ & .052 & .005 & $.142^{* *}$ & .059 & 1 & & & & & \\
\hline & p & .317 & .915 & .006 & .252 & & & & & & \\
\hline & $\mathrm{N}$ & 376 & 376 & 376 & 376 & 376 & & & & & \\
\hline
\end{tabular}




\begin{tabular}{|c|c|c|c|c|c|c|c|c|c|c|c|}
\hline \multirow{3}{*}{$\begin{array}{l}\text { Emotional } \\
\text { Sensitivity }^{6}\end{array}$} & $\mathrm{r}$ & $.283^{* *}$ & $.157^{* *}$ & $.238^{* *}$ & $.226^{* *}$ & $.161^{* *}$ & 1 & & & & \\
\hline & $\mathrm{p}$ & .000 & .002 & .000 & .000 & .002 & & & & & \\
\hline & $\mathrm{N}$ & 376 & 376 & 376 & 376 & 375 & 376 & & & & \\
\hline \multirow{3}{*}{$\begin{array}{l}\text { Emotional } \\
\text { Control }^{7}\end{array}$} & $\mathrm{r}$ & .083 & .029 & .096 & -.002 & -.064 & $.165^{* *}$ & 1 & & & \\
\hline & $\mathrm{p}$ & .110 & .576 & .064 & .964 & .214 & .001 & & & & \\
\hline & $\mathrm{N}$ & 377 & 377 & 377 & 377 & 376 & 376 & 377 & & & \\
\hline \multirow{3}{*}{$\begin{array}{l}\text { Social } \\
\text { Expressivity }^{8}\end{array}$} & $\mathrm{r}$ & $.165^{* *}$ & $.192^{* *}$ & $.235^{* *}$ & $176^{* *}$ & $.121^{*}$ & $.377^{* *}$ & $.165^{* *}$ & 1 & & \\
\hline & $\mathrm{p}$ & .001 & .000 & .000 & .001 & .019 & .000 & .001 & & & \\
\hline & $\mathrm{N}$ & 377 & 377 & 377 & 377 & 376 & 376 & 377 & 377 & & \\
\hline \multirow{3}{*}{ Social Sensitivity } & $\mathrm{r}$ & .071 & $.114^{*}$ & .059 & $.156^{* *}$ & .065 & $.313^{* *}$ & .092 & $.334^{* *}$ & 1 & \\
\hline & $\mathrm{p}$ & .167 & .027 & .255 & .002 & .212 & .000 & .073 & .000 & & \\
\hline & $\mathrm{N}$ & 377 & 377 & 377 & 377 & 376 & 376 & 377 & 377 & 377 & \\
\hline \multirow{3}{*}{ Social Control ${ }^{10}$} & $\mathrm{r}$ & .046 & .037 & $.126^{*}$ & -.003 & .084 & .028 & -.075 & .068 & $-.200^{* *}$ & 1 \\
\hline & $\mathrm{p}$ & .376 & .475 & .015 & .951 & .103 & .586 & .149 & .186 & .000 & \\
\hline & $\mathrm{N}$ & 376 & 376 & 376 & 376 & 375 & 375 & 376 & 376 & 376 & 376 \\
\hline
\end{tabular}

The analysis of Table 3 indicates that there are medium, positive significant correlations between metacognitive dimension of cultural intelligence and emotional sensitivity $(\mathrm{r}=283, \mathrm{p}=.000)$ and social expressivity $(\mathrm{r}=165$, $\mathrm{p}=.001$ ) dimensions of social skills.

There are also medium, positive significant correlations between cognitive dimension of cultural intelligence and emotional sensitivity $(r=157, p=.002)$, social expressivity $(r=192, p=.000)$ and social sensitivity $(r=114, p=.027)$ dimensions of social skills.

The study also finds medium, positive significant correlations between motivational dimension of cultural intelligence and emotional expressivity $(\mathrm{r}=142, \mathrm{p}=.006)$, emotional sensitivity $(\mathrm{r}=238, \mathrm{p}=.000)$, social expressivity $(\mathrm{r}=235, \mathrm{p}=.000)$ and social control $(\mathrm{r}=126, \mathrm{p}=.015)$ dimensions of social skills.

Positive significant correlations also exists between behavioural dimension of cultural intelligence and emotional sensitivity $(\mathrm{r}=226, \mathrm{p}=.000)$, social expressivity $(\mathrm{r}=176, \mathrm{p}=.001)$ and social sensitivity $(\mathrm{r}=156, \mathrm{p}=.002)$ dimensions of social skills.

Table 4. Regression table for students' cultural intelligence to predict their social skills

\begin{tabular}{|c|c|c|c|c|c|c|c|c|}
\hline & & $B$ & $\mathrm{t}$ & $p$ & $R$ & $R^{2}$ & F & $\mathrm{p}$ \\
\hline \multirow{7}{*}{ Cognitive } & Social Skills & & & & .298 & .074 & 5.945 & .000 \\
\hline & Emotional Expressivity & .007 & .127 & .899 & & & & \\
\hline & Emotional Sensitivity & .260 & 4.643 & .000 & & & & \\
\hline & Emotional Control & .033 & .648 & .517 & & & & \\
\hline & Social Expressivity & .069 & 1.233 & .218 & & & & \\
\hline & Social Sensitivity & -.027 & -.485 & ,628 & & & & \\
\hline & Social Control & .032 & .626 &, 532 & & & & \\
\hline \multirow{7}{*}{ Metacognitive } & Social Skills & & & & .216 & .031 & 2.981 & .007 \\
\hline & Emotional Expressivity & -.034 & -.655 & .513 & & & & \\
\hline & Emotional Sensitivity & .093 & 1.618 & .107 & & & & \\
\hline & Emotional Control & -.014 & -.270 & .787 & & & & \\
\hline & Social Expressivity & .144 & 2.501 & .013 & & & & \\
\hline & Social Sensitivity & .043 & .759 & .449 & & & & \\
\hline & Social Control & .025 & .473 & .636 & & & & \\
\hline \multirow{7}{*}{ Motivational } & Social Skills & & & & .325 & 091 & 7.243 & .000 \\
\hline & Emotional Expressivity & .086 & 1.696 & .091 & & & & \\
\hline & Emotional Sensitivity & .166 & 2.997 & .003 & & & & \\
\hline & Emotional Control & .058 & 1.136 & .257 & & & & \\
\hline & Social Expressivity & .159 & 2.841 & .005 & & & & \\
\hline & Social Sensitivity & -.035 & -.635 & .526 & & & & \\
\hline & Social Control & .102 & 1.982 & .048 & & & & \\
\hline \multirow{7}{*}{ Behavioural } & Social Skills & & & & .266 & .056 & 4.656 & .000 \\
\hline & Emotional Expressivity & .006 & .116 & .908 & & & & \\
\hline & Emotional Sensitivity & .180 & 3.185 & .002 & & & & \\
\hline & Emotional Control & -.056 & -1.073 & .284 & & & & \\
\hline & Social Expressivity & .097 & 1.699 & .090 & & & & \\
\hline & Social Sensitivity & .070 & 1.252 & .211 & & & & \\
\hline & Social Control & -.024 & -.456 & .648 & & & & \\
\hline
\end{tabular}


The analysis of Table 4 shows a significant relationship between cognitive dimension of cultural intelligence and social skills $\left(\mathrm{R}=.298, \mathrm{R}^{2}=.074 ; \mathrm{p}<.05\right)$. The analysis of t-test results for the significance of regression coefficients indicates that emotional sensitivity skill $(\mathrm{t}=-4.643, \mathrm{p}=.000)$ predicts the level of cultural intelligence and explains $7.4 \%$ of total variance $(\mathrm{F}(6.367)=5.945, \mathrm{p}<.05)$.

The analysis of Table 4 also indicates a significant relationship between metacognitive dimension of cultural intelligence and social skills $\left(\mathrm{R}=.216, \mathrm{R}^{2}=.031 ; \mathrm{p}<.05\right)$. The analysis of $\mathrm{t}$-test results for the significance of regression coefficients indicates that social expressivity skill $(\mathrm{t}=-2.501, \mathrm{p}=.013)$ predicts the level of cultural intelligence and explains $3.1 \%$ of total variance $(\mathrm{F}(6.367)=2.981, \mathrm{p}<.05)$.

In the analysis of the table, it is also found that there is a significant relationship between motivational dimension of cultural intelligence and social skills $\left(\mathrm{R}=.325, \mathrm{R}^{2}=.091 ; \mathrm{p}<.05\right)$. The analysis of t-test results for the significance of regression coefficients indicates that emotional sensitivity skill $(\mathrm{t}=2.997, \mathrm{p}=.003)$ social expressivity skill $(\mathrm{t}=-2.841, \mathrm{p}=.005)$, social control skill $(\mathrm{t}=1.982, \mathrm{p}=.048)$ are the predictors of cultural intelligence level and explain $9.1 \%$ of total variance $(F(6.367)=7.243, p<.05)$.

Finally, a significant relationship is also found between behavioural dimension of cultural intelligence and social skills $\left(\mathrm{R}=.266, \mathrm{R}^{2}=.056 ; \mathrm{p}<.05\right)$. An examination of t-test results on the significance of regression coefficients indicates that emotional sensitivity skill $(\mathrm{t}=-3.185, \mathrm{p}=.002)$ is the predictor of cultural intelligence level and explains $5.6 \%$ of total variance $(\mathrm{F}(6.367)=4.656, \mathrm{p}<.05)$.

\section{Discussion and Conclusion}

Cultural intelligence encompasses cognitive, motivational and behavioural processes of human psychology and points out a higher cognitive level. Considered as a set of capabilities beyond acquiring cross-cultural communication competency or receiving cross-cultural education, cultural intelligence not only enables individuals to adapt to a single culture but also to create a successful communication environment when they are in a totally foreign culture (Aksoy, 2013). In this framework, establishing mutual and healthy relationships with other people requires certain skills. People interact with each other thanks to such skills called as social skills. Thus, social skills are among the most essential skills for humans as a social being. Social skills have an interpersonal character, aiming to maintain communication and interaction; they can be repeated and identified. The skills of initiating, maintaining and appropriately ending interpersonal relationships are considered within the context of social skills (Bacanl1, 1999).

The concept of cultural intelligence comes into existence in a social environment. In a similar vein, the notion of social skills deals with the individual's relationship with their social environment. In this regard, we can claim that cultural intelligence and social skills are interrelated concepts. Thus, in a strict sense, the concept of social skills referring to the dimension of cultural intelligence that takes place within the society is also related to it. In addition, it can be claimed that students with high level of cultural intelligence and social skills are active and assertive individuals, assuming more roles in an interactive environment related to global arena. In his study examining the academic achievement and social skills of 539 primary school students, Keskin (2007) found that as students' academic achievement increases, their social skills also improve. Gülay (2008) investigated the impact of cooperative plays in physical education class in $9^{\text {th }}$ grade on students' social skills and attitude towards this class. In the comparison of pre-test and post-test results for social skills dimensions and total social skills points for the experimental group that engaged in cooperative plays in physical education class, it was found that there was an increase in emotional expressivity, social sensitivity and social control dimensions. Thus, in our constantly developing world, the successful individuals of the future will be those who will have enhanced their cultural intelligence capacity in the organizational context and received an education based on social skills and qualities.

This study found that the students' scores for cognitive, metacognitive, motivational and behavioural dimensions of cultural intelligence are at a satisfactory level compared to the average scale scores. As for social skills dimensions, it was found that emotional expressivity, emotional sensitivity, emotional control, social expressivity, social sensitivity and social control scores are also at a satisfactory level in comparison to the average scale scores (Table 2). These findings indicate that students' cultural intelligence level may have an impact on their social skills.

In the analysis of Table 3, positive significant relationships are found between metacognitive dimension of cultural intelligence and emotional sensitivity and social expressivity dimensions of social skills. There are also positive significant relationships between cognitive dimension of cultural intelligence and emotional sensitivity, social expressivity and social sensitivity dimensions of social skills. The study found positive significant relationships between motivational dimension of cultural intelligence and emotional expressivity, emotional 
sensitivity, social expressivity and social control dimensions of social skills. Positive significant relationships are also seen between behavioural dimension of cultural intelligence and emotional sensitivity, social expressivity and social sensitivity dimensions of social skills. Socialisation is a process whereby cultural values, customs and traditions of the society are explained to, taught and instilled in children as members of the society (İnanç, 2004), and this process can achieved only within education and training system where the society experiences socialisation and enculturation mostly.

An examination of the prediction of social skills by cultural intelligence reveals that cognitive, metacognitive, motivational and behavioural dimensions are predictor of social skills (Table 4). It can be said that the level of social skills increase with the increase in cultural intelligence. The globalised world has changed the social foundation of educational curricula and caused to reconsider student experience required by constructivist approach in educational curricula. With the spread of means of transportation and mass media, people and communities have become much closer, and people from diverse cultures have interacted with each other more due to such reasons as work, education and tourism. Educational curricula also have changed in many places, particularly in the geographies with high cross-cultural interaction. In his study on the subject, Açikalın (2010) draws attention to the globalized world and underscores the relation of the emphasize on culture with educational curricula. He sheds light on the subject by describing an aspect of culture as global education.

The concept of global education aims to provide a solution to the current global problems with regard to educational curricula (Alger \& Harf, 1985). Starting from global problems such as environment, terrorism and famine, this approach adopted the philosophy of introducing world cultures to students and emerged with the idea of including them in educational curricula (Açıkalın, 2010). Kirkwood (2001) builds global education on four premises. Accordingly, the main premises of global education approach are:

- acquiring multiple perspectives, and knowing and respecting that other people can have ideas or perspectives different from their own;

- understanding and having respect for other cultures;

- $\quad$ having knowledge of global problems and finding solutions for these problems;

- becoming aware of the globalized world and realizing that nations are much more intertwined.

Cultural intelligence is the ability to communicate for the purpose of managing cultural differences in cross-cultural settings as well as embracing, perceiving, interpreting and experiencing other cultures (Mercan, 2016). Social skills are an individuals' capability to understand their own and other people's feelings, ideas and behaviours in social relationships and act according to such understanding (Çubukçu \& Gültekin, 2006).

As is seen in the definitions, our study on these two interrelated concepts indicates that the reason for the impact of cultural intelligence level on social skills is that most of the students in the School of Physical Education and Sports are engaged in individual or team sports, and thanks to the unifying power of sports without discriminating on the basis of religion, language, race and ethnicity, they compete with each other and also respect, understand and constantly communicate with each other while out of competition, and have personality characteristics that will help them to easily adapt to their environment. In addition, one of the reasons for the students' improved cultural intelligence and social skills may be that the School of Physical Education and Sports accommodates many cultures as students from diverse cities and regions of Turkey come here for education.

Consequently, the significance of cultural intelligence and social skills is increasingly growing to maintain successful, healthy and peaceful relationships between people and to create developed educational systems. Besides, people leave their living environment by necessity in today's world of violent conflicts and disasters, resulting in great migration waves. Thus, people from different countries have to live together without planning. On the other hand, the number of foreign students is increasing in almost every country in a time of such easy access to transportation and communication. Taking into account all of these, it has become quite essential to raise highly qualified individuals with high levels of cultural intelligence and social skills. We believe that enhancing people's cultural intelligence and social skills and training them accordingly will naturally improve students in cultural and social aspects, and contribute to providing basis for a healthier world.

\section{Recommendations}

- Artistic and cultural activities that increase socialization in the education system can be promoted.

- Student and teacher exchange programs that improve cultural intelligence and socialization can be disseminated. 
- Sports competitions, festivals or international outdoor student camps that increase communication and interaction between students can be held to enhance cultural socialization.

- Forming international joint study groups, research projects can be conducted.

- Projects that predominantly promote cultural intelligence and social cohesion can be carried out to seek support from international funds.

\section{References}

Açıkalın, M. (2010). Sosyal bilgiler eğitiminde yeni yaklaşımlar. İlköğretim Online, 9(3), 1226-1237.

Aksoy, Z. (2013). Kültürel Zekâ ve Çok Kültürlü Ortamlardaki Rolü. Ege Üniversitesi, Sosyal Bilimler Enstitüsü, Doktora Tezi, İzmir.

Alger, C. F., \& Harf, J. E. (1985). Global Education: Why? For Whom? About What?. American Association of Colleges for Teacher Education, Washington D.C.

Ang, S., Van Dyne, L., Koh, C. K. S., Templer, K. J., Tay, C., \& Chandrasekar, N. A. (2007). Cultural intelligence: Its measurement and effects on cultural judgment and decision making, cultural adaptation and task performance. Management and Organization Review, 3(3), 335-371. https://doi.org/10.1111/j.1740-8784.2007.00082.x

Aydın, G. (1985). Sosyal Başarı Ĕgitimi İle Sosyal Beceri Eğitiminin Çocuklarda Öğrenilmiş Çaresizlik Davranışının Ortadan Kaldırılmasına Etkisi. Yayımlanmamış Doktora Tezi, Hacettepe Üniversitesi Sosyal Bilimler Enstitüsü, Ankara.

Bacanlı, H. (1990). Kendini Ayarlama Becerisinin Çeşitli Değişkenlerle İliş̧kisi. Yayımlanmamış Doktora Tezi, Ankara Üniversitesi Sosyal Bilimler Enstitüsü, Ankara.

Bacanlı, H. (1999). Sosyal Beceri Eğitimi, Ankara, Nobel Yayın Dă̆ıtım, 117-119.

Başaran, İ. E. (1994). Eğitime Giriş (4. Baskı). Ankara: Kadığlu Matbaası.

Çakıl, N. (1998). Grupla sosyal beceri eğitiminin üniversite ögrencilerinin yalnızllk düzeyleri üzerindeki etkisi. Doktora Tezi, Hacettepe Üniversitesi Sosyal Bilimler Enstitüsü.

Çubukçu, Z., \& Gültekin, M. (2006). İlköğretimde Öğrencilere Kazandırılması Gereken Sosyal Beceriler. Bahar Dergisi, 37, 155-174.

Earley, P. C., \& Ang, S. (2003). Cultural intelligence: Individual interactions across cultures. Palo Alto, CA: Stanford University Press.

Ekici, F. Y. (2017). Okul Öncesi Öğretmen Adaylarının Problem Çözme ve Sosyal Beceri Düzeylerinin Incelenmesi. International Journal of Social Sciences and Education Research, 3(1), 16-38. https://doi.org/10.24289/ijsser.283583

Ergün, M., \& Özsüer, S. (2006). Vygotsky'nin Yeniden Değerlendirilmesi. Afyon Karahisar Üniversitesi Sosyal Bilimler Dergisi, 2, 269-292.

Gülay, O. (2008). Ortaöğretim 9. sınıf beden eğitimi dersinde, işbirlikli oyunların öğrencilerin sosyal beceri düzeylerine ve beden eğitimi dersine yönelik tutumlarına etkisi, Abant İzzet Baysal Üniversitesi, Sosyal bilimler enstitüsü.

İnanç, B. Y. (2004). Gelişim psikolojisi çocuk ve ergen gelişimi. Adana: Nobel Kitabevi.

Kalafat, T. (2006). Üniversite Öğrencilerinin Beden Memnuniyeti Düzeyleri İle Sosyal Beceri Düzeyleri Arasındaki IIlişkinin Karşılaş̧tırmalı Olarak Incelenmesi, Yüksek Lisans Tezi, Çanakkale.

Karasar, N. (2015). Bilimsel Araştırma Yöntemi (17.baskı), Ankara: Nobel Yayın Dağıtım, s. 49-53.

Keskin, A. (2007). İlköğretim öğrencilerinin ders başarıları ile sosyal beceri durumlarının incelenmesi. Yüksek Lisans Tezi, Celal Bayar Üniversitesi Sosyal Bilimler Enstitüsü.

Köse, N. (2016). Erasmus Programının Kültürel Zeka Üzerinde Etkisinde Demografik Özelliklerin Rolü Yayımlanmamış Yüksek Lisans Tezi Sosyal Bilimler Enstitüsü Hasan Kalyoncu Üniversitesi.

Mercan, N. (2016). Çok Kültürlü Ortamlarda Kültürel Zekanın Kültürler Arası Duyarlılık İle İlişkisine Yönelik Bir Araştırma. Niğde Üniversitesi, İktisadi ve İdari Bilimler Fakültesi Dergisi, Cilt-Sayl, 9(1), 1-13.

Peterson, B. (2004). Cultural Intelligence: A Guide to Working with People from Other Cultures. Intercultural Press, s.89. 
Riggio, R. E. (1986). Assesment of Basic Social Skills. Journal of Personality and Social Psychology, 51(3), 649-660. https://doi.org/10.1037/0022-3514.51.3.649

Şahin, F., \& Gürbüz, S. (2012). Kültürel Zekâ ve Öz-Yeterliliğin Görev Performansı ve Örgütsel Vatandaşlık Davranış1 Üzerinde Etkisi. Çokuluslu Örgüt Üzerinde Bir Uygulama, 14(2), 123-140.

Segrin, C. (2001). Social Skills and Negative Life Events: Testing the Deficit Stress Generation Hypothesis. Current Psycholog, 1(20), 19-35. https://doi.org/10.1007/s12144-001-1001-8

Şenol, E. (2015). Beden Eğitimi Ve Spor Öğretmenliği İle Eğitim Fakültesi Sinıf Öğretmenliği Öğrencilerinin Sosyal Beceri Düzeylerinin İncelenmesi, Kahramanmaraş Sütçü İmam Üniversitesi, Sağlık Bilimleri Enstitüsü, Yüksek Lisans Tezi, Kahramanmaraş.

Sorias, O. (1986). Sosyal Beceriler ve Değerlendirme Yöntemleri. Psikoloji Dergisi, 5(20), 25-29.

Thomas, D., \& Inkson, K. (2004). Cultural intelligence: people skills for global business. San Francisco, CA: Berrett-Koehler.

Van, D. L., \& Ang, N. T. M. (2007). Cultural intelligence. In S. Clegg \& J. Bailey (Eds.), International encyclopedia of organization studies (1st ed., pp. 345-350). Thousand Oaks, CA: Sage.

Vedadi, A., Kheiri, B., \& Abbasalizadeh, M. (2010). The Relationship Between Cultural Intelligence and Achievement: A Case Study in an Iranian Company. Iranian Journal of Management Studies, 3(3), 27-28.

Walker, H. M., Colvin, G., \& Ramsey, E. (1995). Antisocial behavior in school: Strategies and best practices. Pacific Grove, CA: Brooks/Cole.

Yüksel, G. (2004). Sosyal Beceri Envanteri. Ankara: Asıl Yayınevi.

\section{Copyrights}

Copyright for this article is retained by the author, with first publication rights granted to the journal.

This is an open-access article distributed under the terms and conditions of the Creative Commons Attribution license (http://creativecommons.org/licenses/by/4.0/). 